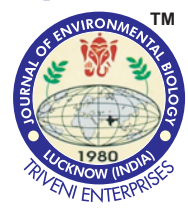

\title{
Phenol degradation and chemical oxygen demand analysis of coir retting wastewater using anaerobic treatment
}

\section{Authors Info \\ K.A.Y. Arafath', S. Gopinath', D. Nilavunesan ${ }^{3}$, S. Sivanesan ${ }^{2}$ and P. Baskaralingam ${ }^{1 *}$ \\ 'Department of Chemistry, Anna University, Chennai-600 025, India \\ ${ }^{2}$ Departmentof Applied Science and Technology, Anna University, Chennai-600 025, India \\ ${ }^{3}$ Departmentof Biotechnology, Sri Venkateswara College of Engineering, Chennai-602 105, India \\ *Corresponding Author Email : baskaralingam@gmail.com}

\section{Edited by}

Professor M. Seenuvasan

Reviewed by

Dr. G. L. Sathyamoorthy

Professor N. K. Dubey

\section{Abstract}

Aim: The objective of this study degradation of phenol, COD using anaerobic treatment by treating coir retting wastewater and biogas production.

Methodology: Sludge from sewage treatment plant was collected from Anna University, Chennai, India. The retting pond wastewater was collected from Coir Industries, Kadayanallur. A laboratory scale cylindrical shaped anaerobic reactor made of glass was used in this study. The total volume of the reactor was 10 litre and the reactor mainly consisted of a cylindrical column of 7 litre capacity (working volume). The anaerobic reactor was fed with 6 litre of sludge and 1.5 litre of coir retting wastewater. The gas produced in the reactor was measured using a gas flow meter.

Results: The retting pond wastewater was treated by lab scale anaerobic reactor. The anaerobic treatment was carried out continuously for 15 days. Parameters such as $\mathrm{pH}$, TSS, TS, MLSS, COD and phenols were analyzed regularly during these evaluations of the reactor performance. The concentration of phenol, TS,TSS and COD decreased gradually with time removal percentage of $76 \%, 96 \%, 91 \%$ and $96 \%$ respectively. About $96 \%$ of total COD wastewater could be converted into biogas.

Interpretation: The results indicate that anaerobic treatment has several advantages in the treatment of retting pond wastewater and also in the production of biogas.

Key words : Anaerobic treatment, Coir retting, Wastewater

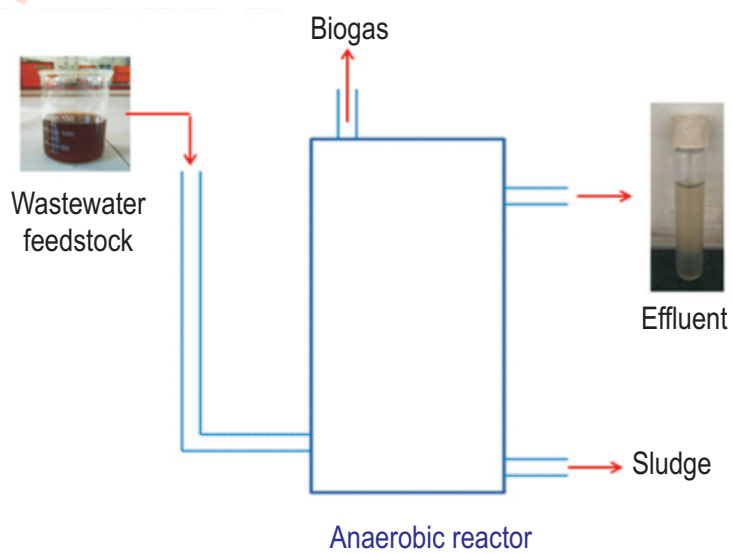

How to cite : Arafath, K.A.Y., S. Gopinath, D. Nilavunesan, S. Sivanesan and P. Baskaralingam: Phenol degradation and chemical oxygen demand analysis of coir retting wastewater using anaerobic treatment. J. Environ. Biol., 40,784-789 (2019). DOI : http://doi.org/10.22438/jeb/40/4(SI)/JEB_20 


\section{Introduction}

The major cause of water pollution is discharge of untreated effluents from industrial, domestic and agricultural activities (Ojha et al., 2015; Abdel-Satar et al., 2017; Kia et al., 2017; Kishi et al., 2017). Among the pollutants, coir retting waste water is considered harmful and contaminate water bodies (Arora et al., 2017); Kadir Turhan and Suheyla Uzman, 2008; Mary Helen et al., 2011). Phenols, aromatic hydrocarbons and their derivatives have been widely found in the coir retting wastewater (Syamkumar et al., 2014). Large quantity of toxic phenols and organic substances like pectin, pentosan, fat, tannins are discharged into water bodies from coir retting units (Basu et al., 2015). These organic compounds without proper treatment can cause serious environmental pollution (Singh and Singh, 2006). The conventional waste water treatment methods for biodegradable organics are not highly efficient (Balcik-Canbolat et al., 2016). The maximum permissible limit for phenol in domestic water is $0.1 \mathrm{mg} \mathrm{l}^{-1}$. These phenolic compounds are toxic to aquatic micro-flora and fauna at low concentration and are lethal to fish at a concentration of 5-25 ppm (Mollaei et al., 2010; Banerjee et al., 2016; Kaur, 2017). Exposure of these phenol pollutants cause serious health issues in humans (Nuhoglu and Yalcin, 2005; Chakraborty et al., 2010). Hence, removal of such harmful phenolic compounds from industrial effluents requires urgent attention (Ucun et al., 2010). Coconut husks are outer jacket obtained from the coir retting processes which are a mjor source of pollution within the domestic fowl backwaters (Shibu et al., 2013). As a result of retting, massive quantity of organic substances together with cellulose, pectosan, fat, tannic acid and poisonous polyphenols are discharged into water bodies (Syamkumar et al., 2014). Several processes have been used to degrade these phenolic compounds present in coir retting wastewater such as granular or biological carbon filtrations, ozonation, chlorination, $\mathrm{H}_{2} \mathrm{O}_{2}$ / actinic ray method, $\mathrm{O}_{3} / \mathrm{UV}$ method, Fenton method, membrane and anaerobic treatment (Karadag et al., 2015), Rajmohan et al. (2016). Martinez et al., (2006). Among these methods, anaerobic treatment is not new and has been practiced for a long time without the need of electric power for the production of bio-methane and renewable energy (Wang et al., 2015; Bishnoi et al. 2006). In anaerobic process, complex biosolids can be efficiently broken down by microorganisms in the absence of oxygen, generating a methane-rich biogas for energy recovery and yielding a stabilized sludge that is suitable for land use (Yaqin 2015; Wang et al., 2015). In view of the above, the present study aimed to treat and degrade phenolic and other harmful organic pollutants present in coir retting wastewater by anaerobic treatment.

\section{Materials and Methods}

Sludge from sewage treatment plant was collected from Anna University, Chennai, India. The retting pond wastewater was collected from Coir Industries, Kadayanallur.
A laboratory scale cylindrical shaped anaerobic reactor made of glass was used in this study. The total volume of the reactor was $10 \mathrm{I}$ and the reactor mainly consisted of a cylindrical column of 7 I capacity (Working Volume). The anaerobic reactor was fed with $6 \mathrm{I}$ of sludge and $1.5 \mathrm{I}$ of coir retting wastewater. The gas produced in the reactor was measured using gas flow meter. Polyphenol concentration and biogas production of retting pond wastewater was estimated by the standard methods of APHA (2012). The Parameters such as pH, TSS, TS, MLSS, COD and phenol were analyzed at regular time intervals. The process was stopped when all the parameters were noticed to be normal / minimal and decreased the mixed liquor suspended solids (MLSS) concentration.

Data analysis was done by Box-Behnken ( ANOVA) at The Predicted $R^{2}$ of 0.9973 is in reasonable agreement with the Adjusted $R^{2}$ of 0.9982 ; the difference is less than 0.2 design experiment. The Model F-value of 2939.70 implies the model is significant. P-values less than 0.0500 indicate model terms are significant.

\section{Results and Discussion}

The anaerobic reactor was filled with anaerobic sludge and slowly adapted step by step, and the retting pond wastewater was fed. The performance of anaerobic reactor was regularly observed. The results showed that the anaerobic treatment of retting pond wastewater is a slow process. They microorganism present in the sludge generally takes some time to consume organic and inorganic matter present in the retting pond wastewater. The process depends on the ambient condition of retting pond wastewater which consist high level of COD and polyphenols. The physico-chemical parameters of pretreated coir retting wastewater such as $\mathrm{pH}$, TS, TSS, COD and phenol analyse are shown in Table 1.

After anaerobic treatment, the parameters such as $\mathrm{pH}$, MLSS, TS, TSS, COD and phenol concentration were analyzed and the results are shown in fig. 1-7.

Anaerobic reactor was fed with activated sludge and the reactor was started with the initial MLSS concentration of 3100 $\mathrm{mg} \mathrm{l}^{-1}$. After the treatment period of 15 days, the final MLSS concentration in the reactor increased to $6750 \mathrm{mg} \mathrm{l}^{-1}$. It was

Table 1: Physico-chemical characteristics of coir retting wastewater

\begin{tabular}{ll}
\hline Parameters & Values \\
\hline pH & $6-8$ \\
TS & $42350 \pm 200$ \\
TSS & $1450 \pm 20$ \\
COD & $32250 \pm 50$ \\
Phenol & $420 \pm 60$ \\
\hline
\end{tabular}

Values are in $\mathrm{mg} \mathrm{l}^{-1}$, except $\mathrm{pH}$ 


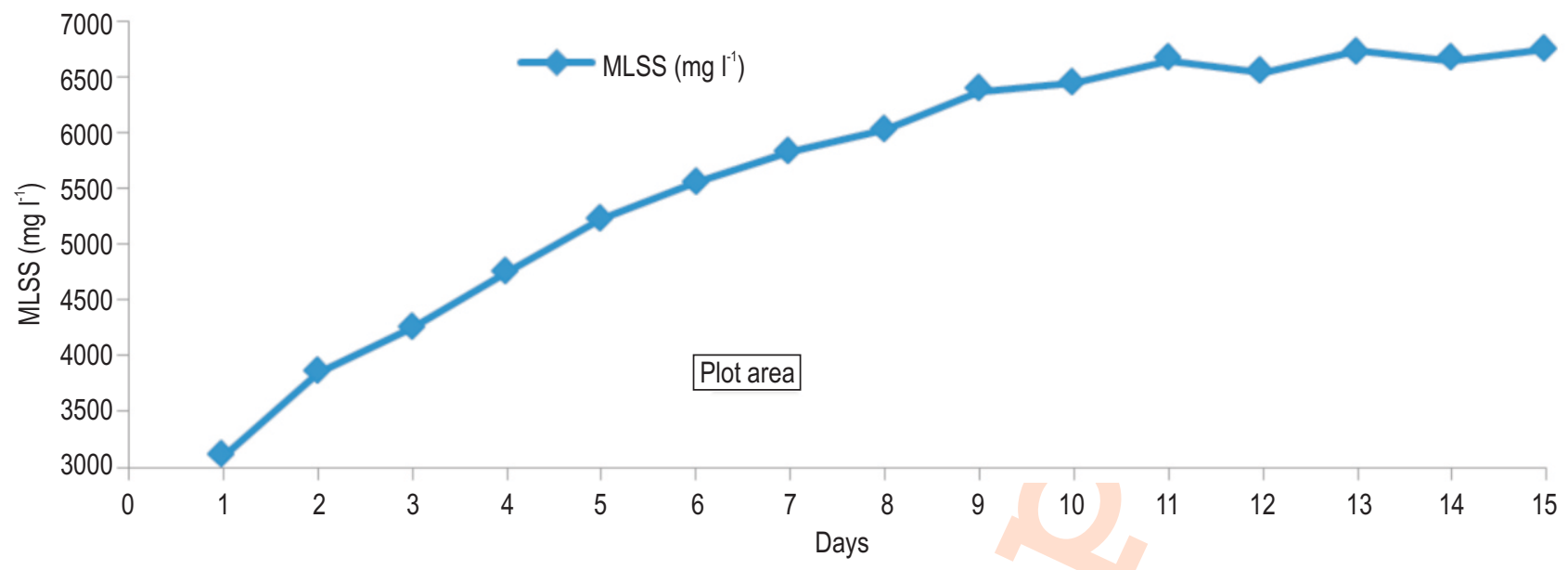

Fig. 1 : MLSS concentration of sludge.

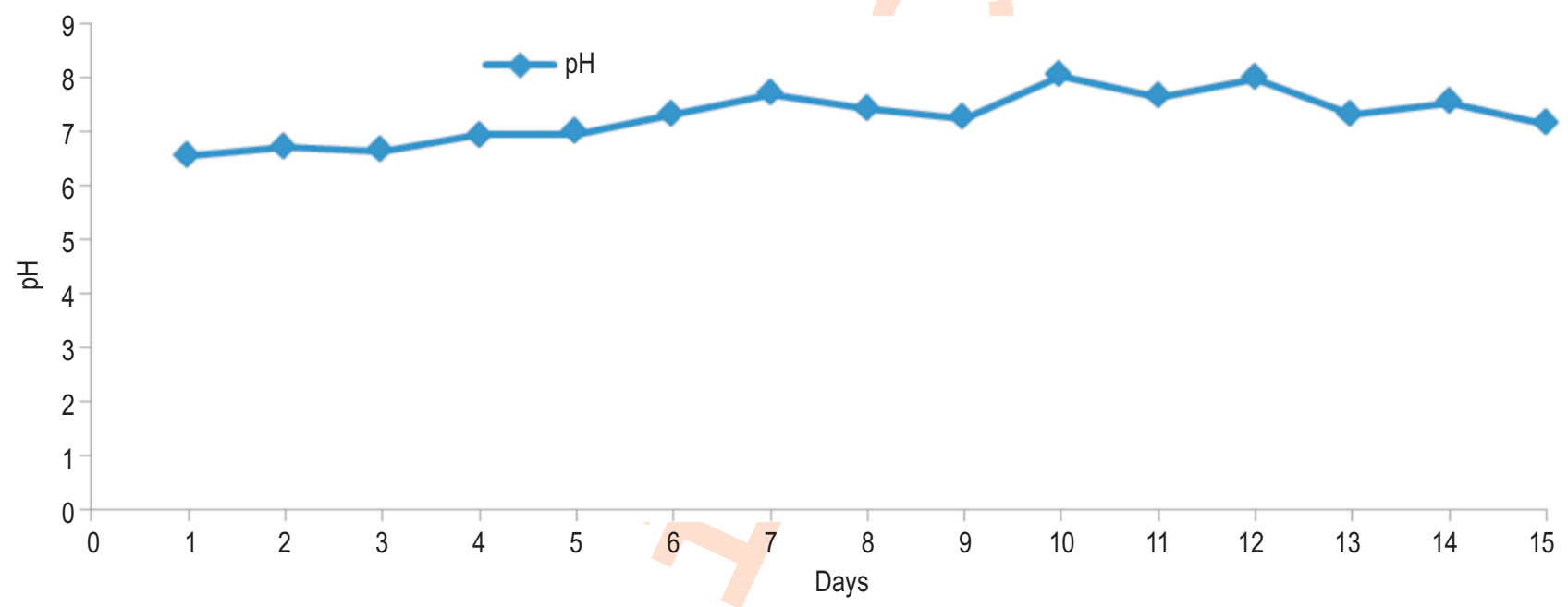

Fig. 2 : pH of effluent wastewater.

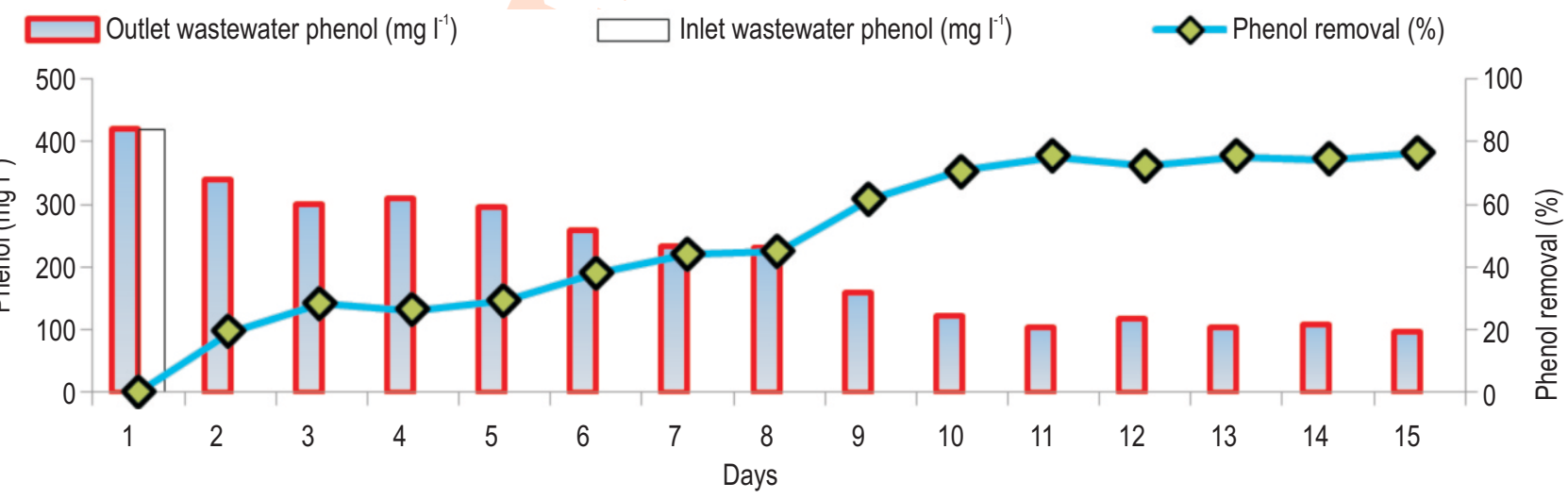

Fig. 3 : Phenol concentration of influent and effluent wastewater.

* Journal of Environmental Biology, Special Issue, July 2019 * 


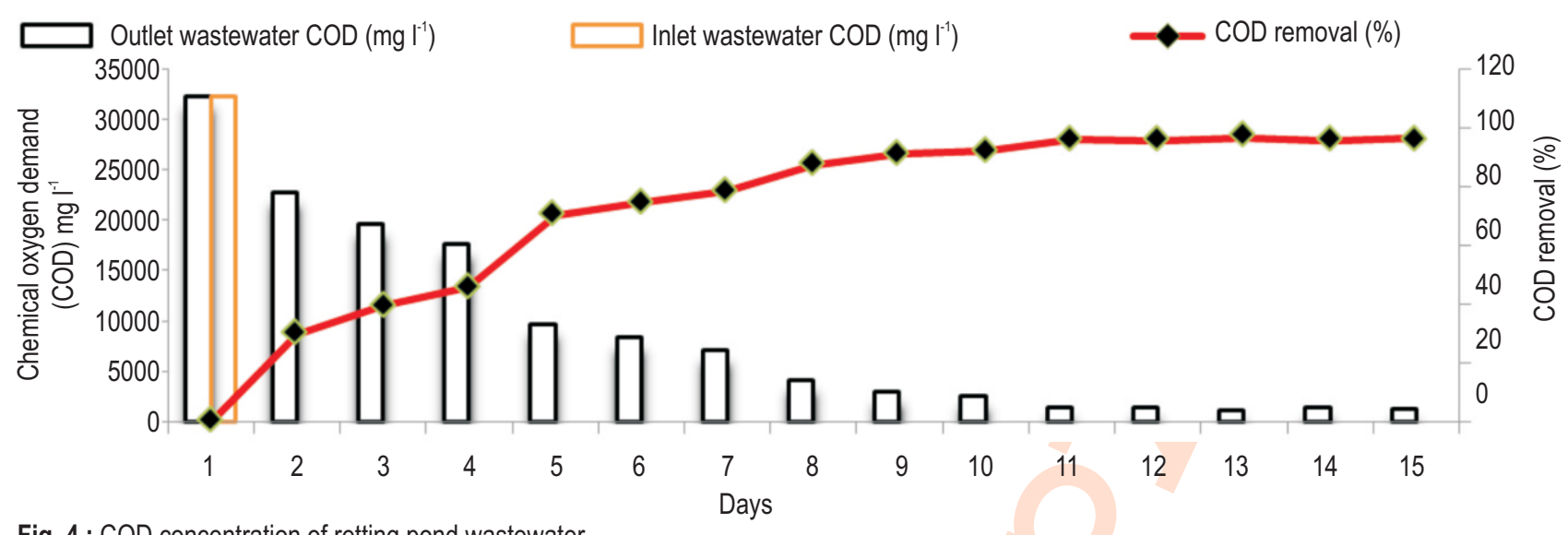

Fig. 4 : $C O D$ concentration of retting pond wastewater.

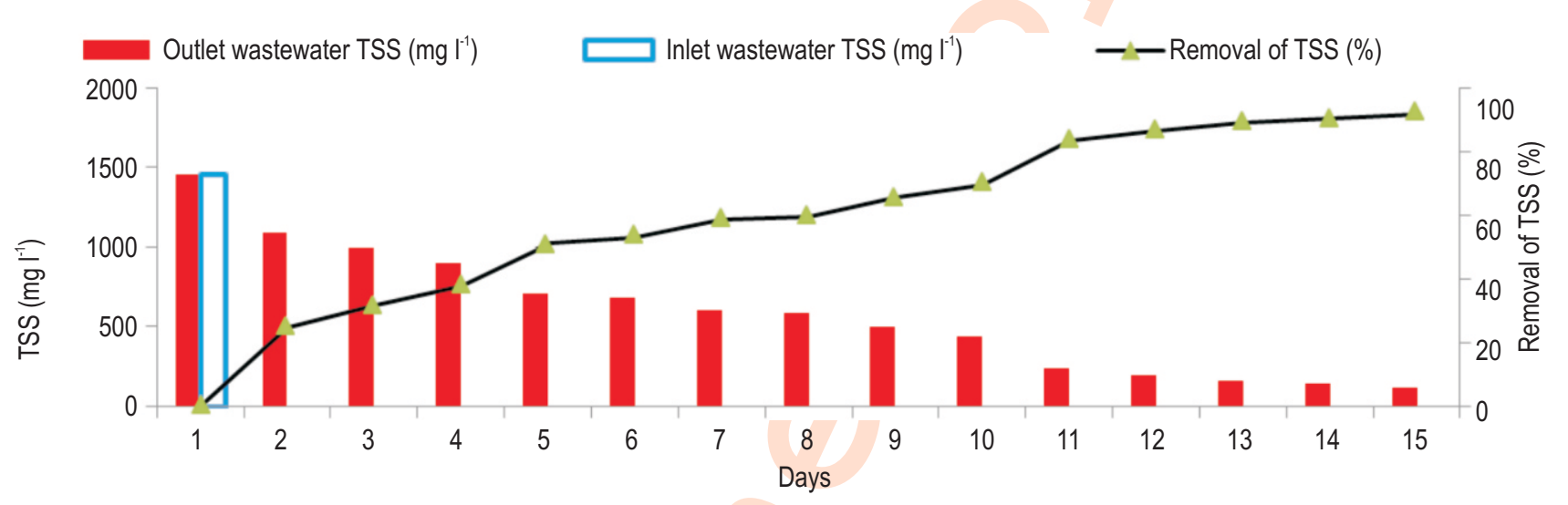

Fig. 5 : TSS concentration of retting pond wastewater.

observed that organic and inorganic matters in the wastewater depend on the utilization of biomass activity (Fan et al., 2015; Kumar et al., 2014). The treatment process was stopped due to an exponential change in MLSS concentration after 10 days. When the MLSS concentration was stable, the removal efficiency of COD, Phenol, TSS, TS ratios were also stable after 10 days.

The perusal of data show that $\mathrm{pH}$ of coir waste water ranged between $6-8$. This is an ideal condition for anaerobic process (Khalid et al., 2011; Mahadevaswamy et al., 2004).The balanced $\mathrm{pH}$ was maintained in anaerobic reactor by carbonic acid.

The retting pond wastewater containing phenols groundwater and land. The initial phenol concentration in retting wastewater was $420 \mathrm{mg} \mathrm{l}^{-1}$ on $1^{\text {st }}$ day of inlet retting pond wastewater. After anaerobic treatment, phenol concentration of effluent retting pond wastewater was $98 \mathrm{mg} \mathrm{I}^{-1}$. The highest phenol removal of $76 \%$ was achieved after 15 days. The accumulation process was slow with sludge and retting pond wastewater after 10 days.

COD removal efficiency increased with time during the treatment of retting pond wastewater. In terms of COD removal, anaerobic process efficiency is seen due to increased MLSS concentration from low $\left(3100 \mathrm{mg} \mathrm{l}^{-1}\right)$ to high $\left(6750 \mathrm{mg} \mathrm{l}^{-1}\right)$ value. COD removal was found to be $96 \%$. The initial COD was found the value of $32250 \mathrm{mg} \mathrm{l}^{-1}$. After the anaerobic treatment, the final COD was found to be $1170 \mathrm{mg} \mathrm{l}^{-1}$. During $12^{\text {th }}$ and $14^{\text {th }}$ day of incubation period, the efficiency of the reactor increased slightly. Due to unstable MLSS concentration, COD removal efficiency decreased after 10 days of anaerobic treatment.

TSS tends to be a straightforward measure of pollutants weight obtained by separating particles from water sample using a filter, the fact that particles occur in nature is essentially a continuum sizes with defined quantity. At bottom, TSS relies on a cut-off based on the filter properties used. At the upper end, the cut-off should be too large to be "suspended" in water to exclude all particles. Removal of total suspended solids was found to be $91 \%$ after 15 days of anaerobic treatment. The initial TSS was found to be $1450 \mathrm{mg} \mathrm{l}^{-1}$. After anaerobic treatment, the final TSS level was $120 \mathrm{mgl}^{-1}$.

Total solids that include the combination of total dissolved solids and total suspended solids. The concentration of total dissolved solids affects the balance of water in aquatic organisms 


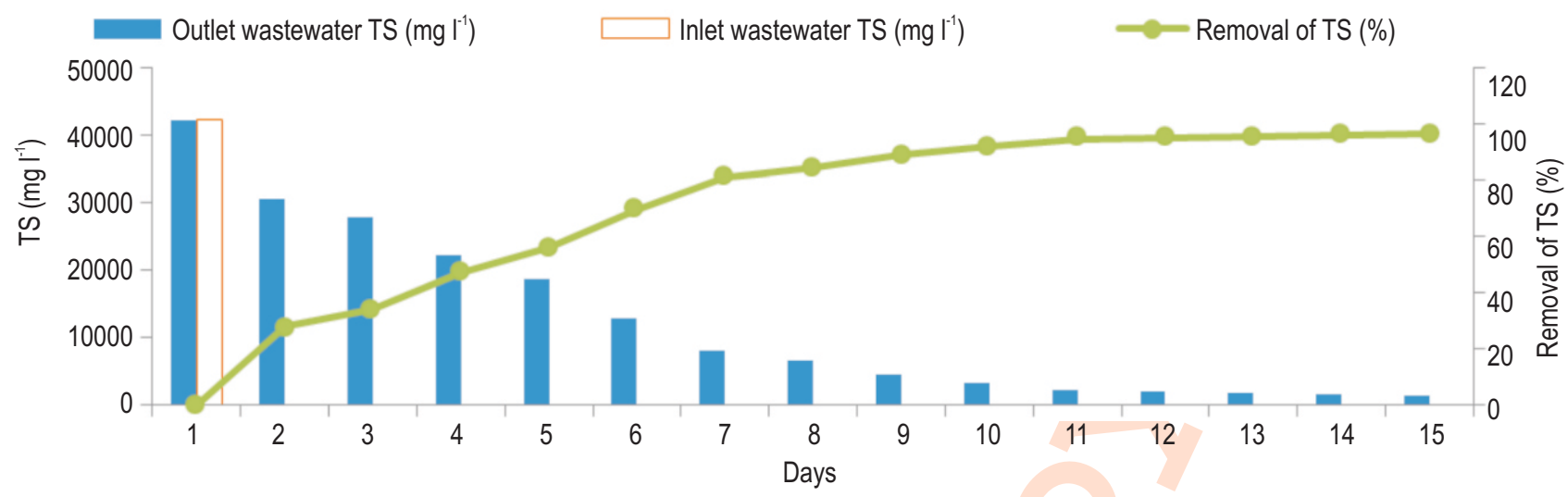

Fig. 6 : TS concentration of retting pond wastewater.

Total biogas production (litre)
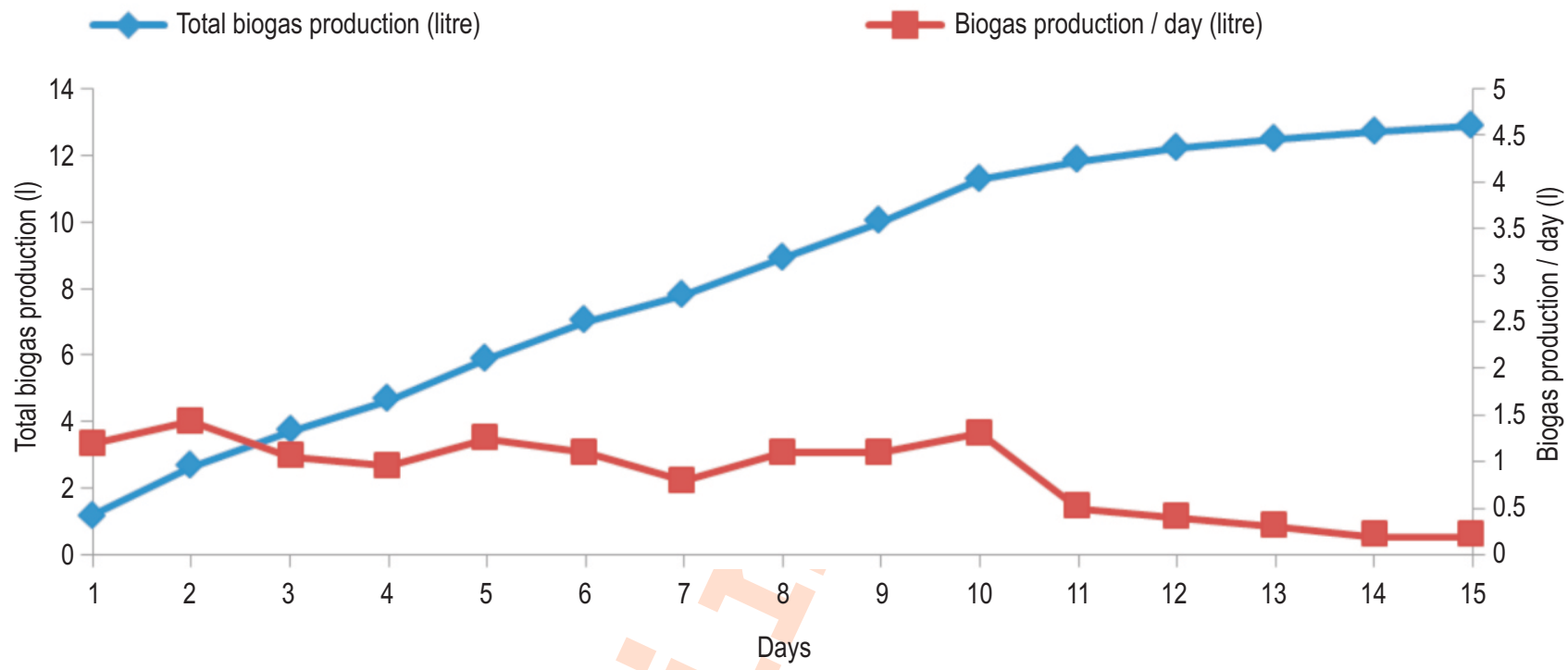

Fig. 7 : Biogas production.

cells. Higher concentrations of suspended solids can serve as hazardous carriers that easily adhere to suspended particles. TS removal of $96 \%$ was achieved after anaerobic treatment. The initial TS were found to be $42350 \mathrm{mg} \mathrm{l}^{-1}$. After anaerobic treatment, the final TS were found to be $1450 \mathrm{mgl}^{-1}$.

Biogas produced during anaerobic experiment was measured by gas flow meter. Total biogas production was found to be 12.9 I after 15 days. Total biogas production increased with time. The amount of dissolved methane in the wastewater affected the intrinsic property of anaerobic process (Jun et al., 2016; Moharram et al., 2016; Elangovan and Sekar, 2016; Agarwal et al., 2001).

The sewage sludge of high phenol concentration of 420 $\mathrm{mg} \mathrm{l}^{-1}$ was degraded in 15 days with $76 \%$ phenol removal in anaerobic reactor. The initial retting pond waste water consisted of high organic which cause more pollution to the environment. Anaerobic treatment of retting wastewater can solve the environmental problem economically. The results of this study highlights the scope of anaerobic treatment of coconut husk retting pond wastewater and generation of methane. Degradability of polyphenols in coconut husk wastewater was not limited and the anaerobic treatment produced the biogas contains about $75 \%$ of methane. The biogas produced can be used as a potential fuel. About $96 \%$ of total COD was converted into biogas in the anaerobic treatment method. The process was found suitable to study in the field.

\section{References}

Agarwal,L.K., H.Harada and H.Okai: Treatment of dilute wastewater in a UASB reactor at a moderate temperature : Performance aspects. J. Ferm. Biotech., 83, 179-184 (2001).

Arora, T., A. Mishra, G. Matta, A. K. Chopra, A. Kumar, D. R. Khanna and V. kumar: Pollution load assessment and potential environmental risks of composite industrial effluents discharged from SIIDCUL integrated industrial estate, haridwar (Uttarakhand), India. J. Environ. Biol., 38, 205-216 (2017). 
APHA.: Standard methods for the examination of water and wastewater, 16th Edn. American Public Health Association, Washington, D.C., USA (2012).

Banerjee, A. and A.K. Ghoshal: Biodegradation of phenol by calciumalginate immobilized Bacillus cereusina packed bed reactor and determination of the mass transfer correlation. J. Environ. Chem. Eng., 4, 1523-1529 (2016).

Banu, J.R., U.D. Khac, S.A. Kumar, Y.I. Tae and S. Kaliappan: A novel method of sludge pretreatment using the combination of alkalis. J. Environ.Biol., 33, 249-253 (2012).

Banu, J.R., S. Kaliappan, M.R. Kumar and D. Beck: Treatment of spent wash in anaerobic mesophilic suspended growth reactor (AMSGR). J. Environ. Biol., 27, 111-117 (2006).

Bishnoi, N.R., R.K. Khumukcham and R. Kumar: Biodegradation of pulp and paper mill effluent using anaerobic followed by aerobic digestion. J. Environ. Biol., 27, 405-408 (2006).

Chakraborty, S., T. Bhattacharya, T.N. Patel and K.K. Tiwari: Biodegradation of phenol by native micro organisms isolated from coke processing wastewater. J. Environ. Biol., 31, 293-296 (2010).

Cigdem, B.C., C. Sengezer, H. Sakar, A. Karagunduz and B. Keskinler: Recovery of Real Dye bath wastewater using integrated membrane process: Considering water recovery, membrane foulingand reuse potential of membranes. Environ. Technol., 38, 19 (2016).

Elangovan, C. and A.S.S. Sekar: Performance evaluation of up flow anaerobic sludge blanket reactor process for dairy wastewater treatment. J. Environ. Biol. ,36, 1305-1310 (2015).

Fan, J., F. Ji, X. Xu, Y. Wang, D. Yan, X. Xu, Q. Chen, J. Xiong and Q. He. Prediction of the effect of fine grit on the MLVSS/MLSS ratio of activated sludge. Biores. Technol., 190, 51-56 (2015).

Basu, G., L. Mishra, S. Jose and A.K. Samanta: Accelerated retting cums oftening of coconut fibre. Indust. Crops and Products, 77, 66 $-73(2015)$.

Gurjar, D.S. and R. Kaur: Impact of wastewater irrigations and planting methods on leaf firing, colour, quality and traffic tolerance of turfgrass. J. Environ. Biol., 39, 117-121 (2018).

Karadag, D., O.E. Köroфglu, B. Ozkaya and M. Cakmakci: A review on anaerobic biofilm reactors for the treatment of dairy industry wastewater. Proc. Biochem., 50, 262-271 (2015).

Khalid, A., M. Arshad, M. Anjum, T. Mahmood and L. Dawson: The anaerobic digestion of solid organic waste. Waste Manage., 31, $1737-1744$ (2011)

Kishi, M., H. Takee, M. Kawai , N. Nagao and T. Toda: Sequential high rate algal pondsoperation for enhanced treatment of organic wastewater. J. Environ. Biol., 39, 835-842 (2018).

Kumar, K., G.K. Singh, M.G. Dastidar and T.R. Sreekrishnan: Effect of mixed liquor volatile suspended solids (MLVSS) and hydraulic retention time (HRT) on the performance of activated sludge process during the biotreatment of real textile waste water. Wat. Res. Ind., 5, 1-8, (2014).

Li, J., T. Xiang, J. Wei, D. Chen and M.A. Ashraf: Effect of COD/SO ratio and alkalinity on COD removal and sulfate reduction in two-phase expanded granular sludge bed. J. Environ. Biol., 37, 1117-1124 (2016).

Mahadevaswamy, M., B.M. Murthy and A.R. Girigamma: Performance evaluation of UP-flow anaerobic sludge blanket (UASB) reactor for treatment of paper mill waste water. J. Environ. Sci., 16, 194-198 (2004).

Martinez, A.B., E. Barbot, B. Marrot, P. Moulin and N. Roche:
Degradation of synthetic phenol-containing waste waters by MBR. J. Membr. Sci., 281, 288-296 (2006).

Mary Helen., P.A, S. Jayasree, J.A. Johnson, I.H.B.J. Edith and Chittarasu: Seasonal variations in physicochemical parameters of water in coconut husk retting area, Parakkani, Tamil Nadu. Int. J. Environ. Sci., 1, 1056-1061 (2011)

Monir, M., S. Abdollahpour, S. Atashgahi, H. Abbasi, F. Masoomi, I. Rad, A.S. Lotfi, H.S. Zahiri, H. Vali and K.A. Noghabi: Enhanced phenol degradation by Pseudomonas sp. SA01: Gaining insight into the novel single and hybrid immobilizations. J. Hazard. Mater., 175, $284-292$ (2010).

Moharram, M.A., H.S. Abdelhalim and E.H. Rozaik: Anaerobic up flow fluidized bed reactor performance as a primary treatment unit in domestic wastewater treatment. HBRC J., 12, 99-105 (2016).

Nakagawa, K., H. Amano, Y. Takao, T. Hosono, R. Berndtsson: On the use of coprostanol to identify source of nitrate pollution in groundwater. J. Hydrol., 550, 663 -668 (2017).

Nuhoglu, A. and B. Yalcin: Modelling of phenol removal in a batch reactor. Proc. Biochem., 40, $1233-1239$ (2005).

Ojha, S.K., S. Mishra, S. Kumar, S.S. Mohanty, B. Sarkar, M. Singh and G.R. Chaudhury: Performance evaluation of vinasse treatment plant integrated with physic-chemical methods. J. Environ. Biol., 36, 1269-1275(2015)

Rajmohan, K.S., M. Gopinath and R. Chetty: Review on challenges and opportunities in the removal of nitrate from wastewater using electrochemical method. J. Environ. Biol., 37, 1519-1528 (2016).

Satar, A.M.A., M.H. Ali and M.E. Goher: Indices of water quality and metal pollution of Nile River, Egypt. Egyp. J.Aqu. Res., 43, 21-29 (2017).

Satyawali, Y., D. Pant, A. Singh and R.K. Srivastava: Treatment of rayon grade pulp drain effluent by upflow anaerobic fixed packed bed reactor (UAFPBR). J. Environ. Biol., 30, 667-672 (2009).

Sethumadhavan, P. and A. M. Selvan V: Effect of spent mushroom substrateand waste paper briquette on methane production from anaerobic digestion. J. Environ. Biol., 39, 269-276 (2018).

Singh,V.K. and J.Singh: Toxicity of industrial wastewater to the aquatic plant Lemna minor L. J. Environ. Biol., 27, 385-390 (2006).

Sivasubramanian, S., S. Karthick and R. Namasivayam: Optimization of parameters for phenol degradation using immobilized Candida tropicalis SSK01 in batch reactor. J. Environ. Biol., 35, 531-536 (2014).

Syamkumar, R., G. Rojith, S. Rajathy and I.S. Bright Singh: Phytotoxicity assessment of coir pith effluent generated during lignin recovery process. Res. J. Chem. Sci., 4, 17-21 (2014).

Turhan, K. and S. Uzman: Removal of phenol from water using ozone. Desalination, 229, 257 -263 (2008).

Ucun, H., E. Yildiz and A. Nuhoglu: Phenol biodegradation in a batch jet loop bioreactor (JLB): Kinetics study and $\mathrm{pH}$ variation. Bioresource Technol., 10, 2965-2971 (2010).

Vardhanan, S.Y., A. Haridas and V.B. Manilal: Closed retting : A Green technology for controlling coir retting pollution of backwaters. J. Environ. Res. Devel., 7, 1523-1530 (2013).

Wang, J., J. Yan and X. Weijun: Treatment of dyeing wastewater by MIC anaerobic reactor. Biochem. Eng. J., 101, 179-184 (2015).

Wei, B., L. Yuan and W. Liu: The effect of organic loading rate on VFA/COD ratio for methane production from an EGSB reactor. $J$. Environ. Biol., 36, 1025-1030 (2015)

Yaqin, Y.: Research on soybean protein wastewater treatment by the integrated two-phase anaerobic reactor. Saudi J. Biol. Sci., 22, 526 $-531(2015)$. 